\title{
Estimation of Dividend Policy on Aggregate and Firm's level: Are Dividends Important for the Resident Shareholder
}

Ilija Gruevski', Stevan Gaber ${ }^{2}$

${ }^{1}$ Goce Delcev University, Faculty of Economics, Krste Misirkov St., 10-A, RepublicofMacedonia, e-mail: ilija.gruevski@ugd.edu.mk

${ }^{2}$ Goce Delcev University, Faculty of Economics, Krste Misirkov St., 10-A, RepublicofMacedonia, e-mail: stevan.gaber@ugd.edu.mk

As part of the firm's general policy, dividend policy deals how the net-earnings after tax are distributed among the shareholders. This article explores the impact of dividend policy on the share price of the firm. Historically, two major academic streams prevailed in finance concerning the dividend policy: the proponents who advocated its importance; and the opponents who defied it. The basic methodological frame used is consisted of the Gordon's model for evaluation of stock prices elaborated in his work "Dividends, Earnings and Stock Prices". Two approaches were followed during the course of our research: macro-analysis with aggregate data; and micro-analysis with individual data. The application of the Gordon's model on aggregate data didn't reveal the true relationship between the policy of distribution of earnings and the movement of reference price index MBI-10. Further analysis of the macro approach detected a handful of possible reasons that led to the inconsistent outcome. Conversely, the regression with micro-data generated significant results proving that Gordon's idea for the relevance of dividend policy is still "alive" at least for the single resident company.

\section{Keywords}

Dividends, Retained Earnings, Dividend Policy, Bird in the Hand Hypothesis, Share Price, Gordon's Model.

\section{Introduction}

The traditional view of corporate policy considers two major questions: where or in what should the company invest, which is associated with the investment decision: and how to cover and finance the investment, also known as the financial decision. The investment decision is usually a product of the capital budgeting process. Commonly, it deals with what real assets should the firm acquire. On the other hand, the financial decision is concerned with how these investments should be financed for example, with debt or equity. However, when the company starts to generate profit, a third decision may be made: how to distribute the profit. The last issue is the central problem of dividend policy, and according to the modern view of corporate policy, is just as important as the other two aspects of the firm's policy. Nevertheless, the final goal of every policy is always to maximize the value of the firm. We may describe the dividend policy as the practice that management follows in making dividend payout decisions, or in other words, the size and pattern of cash distributions over the time to shareholders. [1]. Dividend policy means policy or guideline followed by the management in declaring of dividend. A dividend policy decides proportion of dividend and 
retains earnings. In other words, dividend policy is the firm's plan of action to be followed when dividend decisions are made. It is the decision about how much of earnings to pay out as dividends versus retaining and reinvesting earnings in the firm. So, dividend policy determines the ultimate distribution of the firm's earnings between retention (that is reinvestment) and cash dividend payments of shareholders [2]. As we can see, from above, the dividend policy is all about deciding how to distribute the earnings in the firm, how much in the form of dividends in favor of the shareholder, and how much of the earnings to retain and reinvest back in the firm.

The importance of dividend policy has always been known in a historical context. Even in the early stages of corporate history, managers were aware of the relevance of high and stable dividend payments. Consistent dividend distributions created positive expectations for the future, due to the analogy with the other form of financial security traded, specifically government bonds. Bonds owners received regular and stable interest payment, and corporate managers realized that investors preferred shares that performed like bonds. For example, Bank of North America used to pay dividends after only six months of operation, following the board's policy to distribute dividends regularly out of profits. Accordingly, paying consistent dividends remained of paramount importance to managers during the first half of the 19-th century [3]. Another issue of the modern corporate dividend policy to emerge early in the nineteenth century was that dividends came to be seen as an important form of information. Back in time, investors often received inaccurate and scarce information about the performance of a firm, and used dividend announcements as a way of predicting what management's views about future performance might be. For example, an increase in divided payments was interpreted optimistically about the company's future performance, and consequently, led to rising stock prices. As corporations became aware of this phenomenon, it raised the possibility that managers of companies could use dividends to signal strong earnings prospects and expectations. [4].

We cannot disagree that the dividend policy issue was present since the era of industrial revolution and the birth of modern commercial corporation. But the present-day study of dividend policy has gained academic interest since the middle of the 20-th century. By the 1950's, the effect of dividend policy on firm's value have been hypothesized to a great level among finance scholars. They have attempted to solve several issues pertaining to dividends and formulate theories and models to explain corporate dividend behavior [5]. For the time, we must distinguish one particular publication, to which we may attribute the following "explosion" of theoretical and empirical research, and that is Franco Modigliani \& Merton Miler's "Dividend Policy, Growth, and the Valuation of Shares". Considered as a theoretical "break - through", it has launched the Dividend Irrelevance Hypothesis, confronting the dominant thesis for the significance of dividend policy. As it was revolutionary at its presence, it still remains controversial today, as the assumptions upon it was based greatly differ from conditions of the real economy. Nevertheless, one thing is certain, Modigliani \& Miler have sparked countless debates for the relevance of dividends, spawning a vast amount of literature that a full review of all arguments is not sensible.

All these theoretical controversies may lead to a sort of "dividend enigma" - an unresolved and enduring issues of dividend policy in the field of finance. Black Fisher was absolutely right when he described the dividends as a "puzzle". Or as he stated "The harder we look at the dividends picture, the more it seems like a puzzle, with pieces that just do not fit together" [6]. In this paper we join the everlasting debate for the significance of dividend policy, by trying to answer the question whether the shareholders in North Macedonia prefer high and predictable dividend distributions or maybe, take advantage from redirecting the retentions back into the company. With other words, this is the dilemma of the Bird in the hand hypothesis, claiming that the first choice of the investor would be always to receive the dividend payout. The rationale for this behavior is due to the fact that share prices react more vigorously to the announcement of dividend cash payment, while dividend distributions on regular basis eliminates the uncertainty of future.

Before we continue with our quest for answer, we discuss in short the main theories and models that give authenticity to this specific field of academic interest. 


\section{Review of Dominant Theories in Dividend Policy}

There is a vast amount of theoretical and empirical literature with issues from dividend policy, especially after the publication from Modigliani \& Miler mentioned above. The interesting thing is that there is still no consensus among the academic circles even after decades of extensive research. In the following text we refer to the basic concept and meaning of dividends and dividend policy through the short review of the main theoretical hypothesis present in literature:

Dividend Irrelevance Hypothesis. This theory was primarily introduced by Franco Modigliani \& Merton Miller. Although the publication of their article was widely accepted as the beginning of "renascence" in the research of dividend policy, before the introduction of Dividend Irrelevance Theory, the prevailing opinion was that dividends really matter as high and regular payouts correlated with higher share prices - which is in accordance to the Bird in the Hand Theory. But the new wave demonstrated that under existence of certain assumptions, dividend policies could be irrelevant for the firm.

The assumptions for ideal (perfect) capital market introduced by Modigliani \& Miller are summarized as follows: 1 . There is absence of the tax system (there are no taxes, or in better variant, the tax rates on dividends and capital gains are equal); 2. There are no transaction and flotation costs when securities are traded; All participants in the capital market have free and equal access to all relevant information (free and symmetrical information); 3.There is no conflict between the managers and stockholders (absence of agency cost problem); and 4.All market participants are considered as "price takers" [7].

The authors claimed that the real reason for growth of the stockholder wealth and the share's price lies in the investment decision, not in the decision how the earnings are distributed. Therefore, the investor would be indifferent between dividends and retentions. Accordingly, Modigliani \& Miler concluded that the dividend policy is irrelevant since the firm's value is determined from its ability to generate profits and how much its investments are efficient.

Tax Effect Hypothesis. The proponents of this theory suggest that shareholders prefer low dividend payout ratios since low dividends increase the share's price, thus maximizing the firm's value. Namely, the Dividend Irrelevance Theory assumes the exclusion of every possible tax effect that could eventually influence the outcome of earning distribution (identical tax treatment on dividends and retained earnings). Yet, in the real economy taxes represent a major determinant of the dividend policy. The experience indicates that the countries usually implement differential treatment on various forms of income, for example, dividend income is often taxed with higher rates contrary to retentions. In addition, dividends are taxed on a yearly basis, while taxes on capital gains could be deferred until realization, which means that they are subject to taxation only once when the shares are being sold. It can be seen, that these advantages of capital gains income create "tax induced" preference for the investor to retain, accumulate and reinvest the earning instead to distribute it in a form of dividend payment. Resumed at the bottom line, according to the Tax Effect Hypothesis, shareholders would choose capital gains over dividends and in that sense dividend policy is important factor for valuation of the firm [8], [9].

Bird in the Hand Hypothesis. The basic argument for this theory is that high and regular dividend payouts lead to higher share prices. This alternative hypothesis is better known as the old "traditional" view of dividend policy. In line with thier concept, unsertainty and asymetric information prevail in the real world, thus implicating different valuation of dividends and retained earnings. In such a world investors prefer the "bird in the hand" of cash dividends rather than the "two birds in the bush" of future capital gains [10]. Increasing dividend payments, all things held constant, may be associated with increases in firm value. As a higher current dividend reduces uncertainty about future cash flows, a high payout ratio will reduce the cost of capital, and hence increase share value [11].

Clientele Effects of Dividends Hypothesis. Ever since 1961, Modiglini \& Miler cofirmed that when individual investors design their portfolios, they might be influenced by certain 
market imperfections such as the transaction costs or differential tax rates. This tendency of the investor to choose a specific type of security or portfolo is called "clientele effects of dividend policy". Generally, there are two distinct groups of clientele effects classified in the literature: tax-induced clientele effects and transaction cost-induced clientele effects [12]. However, regerdless the source or reason of the exact clientele effect, taxes and transaction costs are known to increase the cost of capital (or the requared rate of return) and cumulativelly reduce firm's value.

In additon, we describe some possible examples of portfolio choices where clientele effects might be present. For instance, institutional investors such as pension and investment funds or insurance companies, usually track investments in stocks with high dividend pay-out ratios beacuse they enjoy big tax priviledges oposite to the other investors. Similarly, old mature companies that run out of pottential investment alternatives preffer cash dividends, on the other hand start-ups and young firms would choose retentions in order to satisfy their incresed need for capital. Small individual investors such as retirees are oriented towards the stocks with stable and high yielding dividends (liquidity motiv). In the same degree, young individual investors behave analogously, as they have higher propensity to consume. On the contrary, middle aged people tend to acumulate wealt and so, they preffer to invest in low dividend yield securities [13].

The Information Content of Dividends Hypothesis. This theory is otherwise known as the Dividends Signalling Hypothesis. A great number of academics and practitioners discuss that dividends contain an implicit information about the future of a firm. According to them, dividend announcements carry hiden information for the company's potential to generate earnings in the future. Specifically, the carrying signal of future earnings can be defined in a double sense: in a sense of stability; and in a sense of change in the course of dividend policy. This new academic suggestion was named "information content of dividends" or "dividends signaling effect"[14].

Really, there is much evidence to indciate that companies tend to increase dividend payouts only in the case of permanent and sufficient growth of their earnings. This approach in dividend policy assumes longterm realisation of sustainable earnings, which is consistent with the foundations of the Dividend - Smoothing Hypothesis. And that is - managers are prone to smooth the dividends over time, never announcing disproportionaly high dividends unless they aren't capable to boost their future growth.

Sometimes, the signals of dividend policy might be missinterpreted on the market. For example, in may 1994 Florida Power \& Light Company announced 32\% decrease of its quarterly dividend payment. Instantly, the market reacted adequatelly upon the information resulting with $20 \%$ decrese of the firm's stock value. This was due to the wrong perceptions about „bad“ performance in future, but actually, the Board decided to keep the available funds for new investment. Only after the true was reveiled in public and the investors realised that this move was not cosequent to internal crises, the share's price rebounded. The case study of FLP Group represents a classical example of how dividend policy might be trully contradictory, if the carrying information is not unerstood properly [15].

Agency Costs Hypothesis. In Dividend Irrelevance Theory, Modigliani \& Miller assume that there is no conflict of interest between managers and stockholders. But in practice this assumption is not correspondent with the reality. In fact, it seems that managers are imperfect agents of their principals - the shareholders, if we account that managerial interest is not necessarily identical with the owner's. Managers take actions that are fairly costly to the owner, such as high managerial fees, different provisions, large donations and promotion costs etc. These all create an additional "agency" costs for the principal, in order to monitor and control the managerial activities and behavior. From this point of view, the protagonist of this theory observe the dividend distributions as a favorable mean for "equalization" of the existing interests within the firm and also, as an effective instrument to control (or avoid) the "agency" cost problem. Actually, with the policy of dividend cash-outs to managers, the principals are able to "tie" the managerial and the owner's interest which in turn reduces the agency costs. [16], [17]. 


\section{Empirical Evidence of „Bird in the Hand" Theory}

In the context of this theory, if the expected cash flows are uncertain, the rational investor would preffer „a bird in the hand" rather than „a bird in the bush". With other words, he would give advantage to dividends than to retained earnings. In 1959, Gordon explained in an original manner that there were three possible reasons for why investors would buy a certain stock: first to obtain both dividends and earnings second, to obtain dividends, and finally to get the earnings [18]. However, he didn't finish his proposition only by simple suggestion, he aslo tried to prove it empirically. Gordon examined these hypotheses by estimating different regression models using a crosssection sample data of four industries (chemicals, foods, steels, and machine tools) for two years 1951 and 1954. The regression model he used to test the Bird in the Hand Hypothesis (or the Dividend Hypothesis) was acording to the expression:

$$
\text { Price }_{i t}=\alpha_{0}+\alpha_{1} \text { Div }_{i t}+\alpha_{2} \text { Ret }_{i t}+\varepsilon_{i t}
$$

where, for firm $i$ and period $t$, Price, Div, and Ret are the share price, dividends, and the retained earnings, respectively, $\alpha_{1}$ is the regression coefficient on dividends (the reciprocal of $\alpha_{1}$ represents the estimated required rate of return on shares), and finaly $\alpha_{2}$ is the regression coefficient on retained earning. In the reserch, author Gordon found that dividends have greater impact on share price over retained earnings. In addition, he proved that the required rate of return on a share increases with the fraction of retained earnings because of the uncertainty associated with future earnings. In the same conotation, Gordon argued that higher dividend payouts decrease the cost of equity or the required rate of return on equity [19]. Using data collected from the UK for the period between 1949 and 1957, Fisher reached a similar conclusion that dividends have greater influnce on share price compared to retentions. [20]. Furthermore, Graham and Dodd managed to scale the effect on stock price, claiming that a dollar of dividends has, on average, four times stronger impact on stock prices against a dollar of retained earnings [21]. Other empirical studies that support the basic argument of this theory - that high dividends increase the share value, come from Linter [22] and Walter [23].

There is also a great deal of critisizm for this theory. Interestingly, Modigliani \& Miller are among the loudest opponents who argued that the firm's risk is determined by the riskiness of its operating cash flows, not by the way it distributes its earnings. They called this anomaly "bird-in-the-hand fallacy" [24]. Additionally, they explainned that the riskiness of a firm's cash flow influences its dividend payments, but increases in dividends will not reduce the risk of the firm (the required rate of return). In short, firm's risk affects the level of dividend payout not the other way around. Rozeff is another sceptic as he found a negative relationship between dividends and firm's risk [25].

Even Gordon's equation wasn't immune to negative reviews. The critics are summarized in the following points: 1.The equation assumes that the firm's growth comes only from reinvestments of retained earnings. Ignoring the investments financed by external funds might bias the regression coefficient $\alpha_{2}$. 2. It doesn't account for the difference in the risk level associated with the specific industry, which in turn can bias the regression coefficient of dividends $\alpha_{1}$; and 3 . Reatained earnings can not be measured properly as dividends, because they are dependend on the apllied accounting procedure. Once again, this might produce false retention coefficient $\alpha_{2}$ [26].

There are attempts to correct the potential bias critisized from above. For that purpose, Diamond modiffied the regression equation discussed in [1] with introduction of additional variable of the lagged earning-price ratio $t_{t-1}$ [27]. Once again, the research tracked only weak support for the preference of dividends over retained earnings. Maybe Diamond failed to correct and find significant evidence for the Gordons hypothesis, but what his real contribution here is that he found strong inverse relationship between the firm's growth and 
dividend payout. Namely, in the industries where rates of growth were relatively high, retained earnings were preferred marginally more than dividends, whereas in mature industries with low growth rate a dollar of ividends is slightly preferred to a dollar of retained earnings [28]. With other words, growing young firms give advantage to retentions, while the old mature ones to dividends.

Even the more contemporal studies give pesimistic results concerning this theory. Recently, in 2002, Baker, Powell and Veit investigated the managers of NASDAQ firms to assess their opinion about dividend policy issues. Their research included a questionnaire with statments about the observed hypothesis. Asked if the investors prefer cash dividends today to uncertain future price appreciation, only 17.2 percent agreed with the statement, 28 percent had no opinion, and 54.9 percent disagreed [29]. These findings may be subjective, however they stipulate once again the inconclusive nature of dividends, stil remaining to „puzzle" the accademic comunity.

\section{The research}

„What do macedonian stockholders preffer: dividends or reatined earnings". This is the question we try to solve here in this section. Motivated by the everlasting debate of dividend policy, we decided to participate and test "the Bird in the Hand Hypothesis" on domestic terrain. Has uncertainty of the future cashflows affected the decision of macedonian managers to distribute dividends, or maybe the possibilities for expansion were another reason to withhold and reinvest the earnings? Since it is impossible to evaluate every single company for the purpose of the reserch, we centered our attention on the best 10 companies that constitute the MBI-10 index. The idea is through application of the Gordons model to examine weather the marginal change of dividends or reatined earnings (as a result of the earnings distribution policy) had any signifficant influence on share price. But first, before the data is presented, we describe the internal policy of firms for distribution of earnings.

The policy for distribution of earnings. According to the internal laws, the companies quoted on MSE - The Macedonian Stock Exchange, are obligated to report how their annual net-earnings are distributed. The distribuition of earnings is subject of discretionary decision, made by the General Shareholder's Assembly in coordination with The Board of Directors. Most commonly, the available earning funds are divided for dividends, usually paid to the residual owners - the stockholders, or allocated in a form of retained earning ready to be reinvested if an opportunity occurs. Sometimes, but very rare, if there are no any investment alternatives, accumulated earnings can be spent for dividends. Normally, the available earnings can be distributed for other purposes except for dividends and retentions, such as for loss reserves (general, statutary or mandatory) or for share repurchase funds. Of course, the earnings by itself can also serve as a medium for loss compensation. Considering this when the data was prepared, only the cash transfers for dividends made from the available earning funds were classified as dividends, and all the rest items such as retentions, accumulations, reserves, repurchase funds and loss compensation entered into the category of retained earnings.

Information about the data is presented below.

Table 1 Distribution of earnings in million denars (Alkaloid, Granit, Makpetrol, Telekom and Stopanska Banka - Skopje)

\begin{tabular}{ccccccccccc}
\hline & \multicolumn{2}{c}{ ALK } & \multicolumn{2}{c}{ GRNT } & \multicolumn{2}{c}{ MPT } & \multicolumn{2}{c}{ TEL } & \multicolumn{2}{c}{ STB } \\
\hline & div & ret ear & div & ret ear & div & ret ear & div & ret ear & div & ret ear \\
\hline $\mathbf{2 0 1 7}$ & 359 & 346 & 78 & 130 & 112 & 219 & 1251 & 0 & 2218 & 22 \\
\hline $\mathbf{2 0 1 6}$ & 329 & 316 & 62 & 137 & 0 & 13 & 1475 & 0 & 2776 & 1916 \\
\hline $\mathbf{2 0 1 5}$ & 300 & 328 & 47 & 129 & 0 & 0 & 3504 & 0 & 0 & 1512 \\
\hline $\mathbf{2 0 1 4}$ & 318 & 302 & 47 & 300 & 0 & 0 & 2716 & 0 & 0 & 989 \\
\hline $\mathbf{2 0 1 3}$ & 291 & 316 & 35 & 306 & 0 & 0 & $/$ & $/$ & $/$ & $/$ \\
\hline $\mathbf{2 0 1 2}$ & 370 & 235 & 44 & 347 & 0 & 25 & $/$ & $/$ & $/$ & $/$ \\
\hline $\mathbf{2 0 1 1}$ & 364 & 216 & 29 & 270 & 0 & 0 & $/$ & $/$ & $/$ & $/$ \\
\hline $\mathbf{2 0 1 0}$ & 315 & 187 & 59 & 310 & 0 & 0 & $/$ & $/$ & $/$ & $/$ \\
\hline
\end{tabular}




\begin{tabular}{lllllllllll}
\hline $\mathbf{2 0 0 9}$ & 318 & 132 & 67 & 396 & 112 & 150 & $/$ & $/$ & $/$ & $/$ \\
\hline $\mathbf{2 0 0 8}$ & 267 & 151 & 67 & 267 & 112 & 49 & $/$ & $/$ & $/$ & $/$ \\
\hline $\mathbf{2 0 0 7}$ & 125 & 127 & 66 & 360 & 112 & 176 & $/$ & $/$ & $/$ & $/$ \\
\hline \multicolumn{8}{c}{ Source: MSE }
\end{tabular}

Table 2 Distribution of earnings in million denars (Tutunska Banka, Stopanska Banka - Bitola, Ohridska Banka, Komercijalna Banka and Makedonija Turs)

\begin{tabular}{ccccccccccc}
\hline & \multicolumn{2}{c}{ TNB } & \multicolumn{2}{c}{ SBT } & \multicolumn{2}{c}{ OHB } & \multicolumn{2}{c}{ KMB } & \multicolumn{2}{c}{ MTUR } \\
\hline & div & ret ear & div & ret ear & div & ret ear & div & ret ear & div & ret ear \\
\hline $\mathbf{2 0 1 7}$ & 850 & 729 & 0 & 30 & 43 & 391 & 342 & 437 & 76 & 24 \\
\hline $\mathbf{2 0 1 6}$ & 582 & 249 & 0 & 7 & 40 & 359 & 285 & 340 & 84 & 28 \\
\hline $\mathbf{2 0 1 5}$ & 472 & 202 & 0 & 159 & 0 & 232 & 0 & 95 & 76 & 52 \\
\hline $\mathbf{2 0 1 4}$ & 0 & 625 & 0 & 21 & 0 & 0 & 0 & 78 & 84 & 109 \\
\hline $\mathbf{2 0 1 3}$ & $/$ & $/$ & 0 & 0 & 0 & 128 & 247 & 314 & 88 & 104 \\
\hline $\mathbf{2 0 1 2}$ & $/$ & $/$ & 0 & 0 & 0 & 35 & 496 & 590 & 82 & 99 \\
\hline $\mathbf{2 0 1 1}$ & $/$ & $/$ & 0 & 15 & 0 & 27 & 496 & 935 & 84 & 101 \\
\hline $\mathbf{2 0 1 0}$ & $/$ & $/$ & 77 & 5 & 0 & 24 & 380 & 694 & 80 & 106 \\
\hline $\mathbf{2 0 0 9}$ & $/$ & $/$ & 93 & 90 & 0 & 26 & 382 & 996 & 72 & 119 \\
\hline $\mathbf{2 0 0 8}$ & $/$ & $/$ & 199 & 58 & 0 & 93 & 380 & 766 & 62 & 86 \\
\hline $\mathbf{2 0 0 7}$ & $/$ & $/$ & 186 & 13 & 0 & 119 & 331 & 417 & 55 & 61 \\
\hline
\end{tabular}

Table 3 Total (aggregate) amount of dividends and retained earnings (in millions denars and \%)

\begin{tabular}{lcccccccc}
\hline & \multicolumn{4}{c}{ Total (aggregate) } & \multicolumn{4}{c}{ Total (without TEL, STB and TNB) } \\
\hline & div & ret ear & \% div & \% ret ear & Div & ret ear & $\%$ div & $\%$ ret ear \\
\hline $\mathbf{2 0 1 7}$ & 5329 & 2328 & 0,695964 & 0,304036 & 1010 & 1577 & 0,390414 & 0,609586 \\
\hline $\mathbf{2 0 1 6}$ & 5633 & 3365 & 0,626028 & 0,373972 & 800 & 1200 & 0,4 & 0,6 \\
\hline $\mathbf{2 0 1 5}$ & 4399 & 2709 & 0,61888 & 0,38112 & 423 & 995 & 0,298307 & 0,701693 \\
\hline $\mathbf{2 0 1 4}$ & 3165 & 2424 & 0,566291 & 0,433709 & 449 & 810 & 0,356632 & 0,643368 \\
\hline $\mathbf{2 0 1 3}$ & 661 & 1168 & 0,3614 & 0,6386 & 661 & 1168 & 0,3614 & 0,6386 \\
\hline $\mathbf{2 0 1 2}$ & 992 & 1331 & 0,427034 & 0,572966 & 992 & 1331 & 0,427034 & 0,572966 \\
\hline $\mathbf{2 0 1 1}$ & 973 & 1564 & 0,383524 & 0,616476 & 973 & 1564 & 0,383524 & 0,616476 \\
\hline $\mathbf{2 0 1 0}$ & 911 & 1326 & 0,407242 & 0,592758 & 911 & 1326 & 0,407242 & 0,592758 \\
\hline $\mathbf{2 0 0 9}$ & 1044 & 1909 & 0,353539 & 0,646461 & 1044 & 1909 & 0,353539 & 0,646461 \\
\hline $\mathbf{2 0 0 8}$ & 1087 & 1470 & 0,425108 & 0,574892 & 1087 & 1470 & 0,425108 & 0,574892 \\
\hline $\mathbf{2 0 0 7}$ & 875 & 1273 & 0,407356 & 0,592644 & 875 & 1273 & 0,407356 & 0,592644 \\
\hline Вкупно & $\mathbf{2 5 0 6 9}$ & $\mathbf{2 0 8 6 7}$ & $\mathbf{0 , 5 4 5 7 3 8}$ & $\mathbf{0 , 4 5 4 2 6 2}$ & $\mathbf{9 2 2 5}$ & $\mathbf{1 4 6 2 3}$ & $\mathbf{0 , 3 8 6 8 2 5}$ & $\mathbf{0 , 6 1 3 1 7 5}$ \\
\hline
\end{tabular}

Source: MSE

The regression model. In addition we investigate if the different categories of distributed earnings had any effects on the share price and what is the intensity of those possible effects. Weather the prices react when dividends and retentions change on a marginal level, and which reaction is stroger. If the prices move positively and with higher intensity when dividends change, we will consider this as a formal confirmation of "the Bird in the Hand Hypothesis" existing on the Macedonian capital market, and that the stockholders prefer dividends in front of retained earnings. One reliable method for the purpose is the Gordon's model initially constructed for panel-data research of individual firms, but in our case we are going to use aggregate data in the equation. Therefore, if for the period $i, M B / 10$ index represents the aggregate price index on the official market, Div represents the aggregate amount of dividends, Ret is the aggregate amount of earnings retained, $\alpha_{0}$ is the intercept, $\alpha_{1}$ symbolizes the regression coefficient of dividends, $\alpha_{1}$ is the regression coefficient of retentions and $\varepsilon$ is residual, than the applied model can take the form of:

$$
\text { MBI10index } i=\alpha_{0}+\alpha_{1} \text { Div }_{i}+\alpha_{2} \text { Ret }_{i}+\varepsilon_{i}
$$


Presumably, the results indicate that aggregate dividends have small but positive impact on the price index $\mathrm{MBI}$, on the other hand the aggregate amount of retained earnings generate stronger but negative effect on the price index MBI. This is according to the observed hypothesis, but after all, these findings are inconclusive and irrelevant because the regression coefficients are statistically insignificant ( $p$-value $>0,05)$.

Table 4 OLS regression results

\begin{tabular}{|c|c|c|c|c|c|c|c|c|}
\hline & \multicolumn{2}{|c|}{ Coefficientstandard Err } & t Stat & $P$-value & Lower 95\% & Jpper 95\% & wer $95,0^{\circ}$ & pper 95,0\% \\
\hline ept & 4167,551 & 2510,908 & 1,659778 & 0,135541 & $-1622,61$ & 9957,716 & $-1622,61$ & 9957,716 \\
\hline X Variable & 0,150479 & 0,755698 & 0,199126 & 0,847132 & $-1,59216$ & 1,893122 & $-1,59216$ & 1,893122 \\
\hline X Variable & $-1,00615$ & 2,071218 & $-0,48578$ & 0,640149 & $-5,78239$ & 3,770083 & $-5,78239$ & 3,770083 \\
\hline
\end{tabular}

Source: Author's calculations

As we can see, the regression doesn't reveil the true relationship between the observed variables. One possible reason for this may be the acquired incorrect or incomplete data. Indeed, according to the tables, there is lack of information for 3 companies: Telekom, Stopanska Banka - Skopje and Tutunska Banka between 2007 and 2013. To correct the inconsistensy detected, we excluded these companies from the aggregate ammounts of both independent variables, but unfortunately, it was impossible to remove out their contribution (share of weight) from the dependent variable - the price index MBI. Running the regression again only slightly improved the findings:

Table 5 OLS regression results

\begin{tabular}{|c|c|c|c|c|c|c|c|c|}
\hline & \multicolumn{2}{|c|}{ Coefficientstandard Err } & \multirow{2}{*}{$\frac{t \text { Stat }}{0.777168}$} & \multirow{2}{*}{$\frac{P \text {-value }}{0,459421}$} & \multicolumn{4}{|c|}{ Lower 95\% Upper 95\%.ower 95,0\%/pper 95,0\% } \\
\hline Intercept & 2130,606 & 2741,501 & & & $-4191,31$ & 8452,517 & $-4191,31$ & 8452,517 \\
\hline & 999 & 612 & 0,495401 & 0,633637 & 313 & & 9313 & 14,37852 \\
\hline ret ear & $-1,24961$ & 3,972729 & $-0,31455$ & 0,761152 & $-10,4107$ & 7,91152 & $-10,4107$ & 7,91152 \\
\hline
\end{tabular}

Source: Author's calculations

The repeated regression produced inconsistent results once again, this time with higher regression coefficient of dividends as a consequence of data sinchronization. The intercept and the coefficients are invalid and statistically insignifficant. There might be couple of reasons behind this: existnence of hidden independent variable in the model, incorrect or incomplete data, insufficient data (small number of observations), incompatible price index etc. The portfolio of included firms can be problematic too. Many of them come from the financial sector and those firms, especially banks are known to distribute enormouse ammounts of reserves to offset the potential loss from lending. In that direction, to use segregated data according the sector involved would be much plausable option here.

A conclusion can be drawn from this, that the application of the Gordon's model with aggegate data on a macro level didn't yield the expected results and the general policy for distribution of earnings was not recognised as a determinant of the aggregate price index. After all, reference indexes are under influence of many variables, and may not be sutable in the particuilar case. That's why in the next section we'll take different approach and investigate how "the Bird in the Hand Theory" works on a micro level.

Aiming to construct statistically significant regression, we turned our attention to examine how the model works on a level of single company, specifically AD Alkaloid - Skopje. But this time the basic regression was extended with fixed (dummy) variable to split the years when the economic/financial crisis left its greatest impact. This is important, because share prices can undergo serious fluctuations as a result of the external shocks generated by the crisis. Dummies are introduced to stabilize these variations, and so we write 1 , for the years of the financial crisis, otherwise 0 . If we add the dummy variable the equation will transform to:

$$
\operatorname{Price}(A L K)_{i}=\alpha_{0}+\alpha_{1} \operatorname{Div}(A L K)_{i}+\alpha_{2} \operatorname{Ret}(A L K)_{i}+d u m m y_{i}+\varepsilon_{i t}
$$


where every symbol has the same meaning and the abbreviation ALK stands for $A D$ Alkaloid - Skopje (for example, Price $(A L K)_{i}$ is the share price of $A D$ Alkaloid Skopje in period $i$ ).

This time the results are more confident: the both coefficients and the intercept are significant with $p$-value lower then 0,05 . They indicate that for every million denars in dividend payment the share price increases by 39 denars, and for every million denars retentions withheld the price decreases by 41 denars.

Table 5 OLS regression results

\begin{tabular}{|c|c|c|c|c|c|c|c|c|}
\hline \multicolumn{9}{|c|}{ SUMMARY OUTPUT } \\
\hline \multicolumn{9}{|c|}{ Regression Statistics } \\
\hline \multicolumn{9}{|c|}{$\begin{array}{ll}\text { Multiple R } & 0,937322\end{array}$} \\
\hline \multicolumn{9}{|c|}{ R Square 0,878573} \\
\hline \multicolumn{9}{|c|}{ Adjusted $\mathrm{F} \quad 0,826532$} \\
\hline \multicolumn{9}{|c|}{ Standard E 736,1748} \\
\hline \multicolumn{9}{|c|}{ Observatio $\quad 11$} \\
\hline & & & & & & & & \\
\hline \multicolumn{9}{|l|}{ ANOVA } \\
\hline & $d f$ & SS & $M S$ & $F$ & ignificance & $F$ & & \\
\hline Regressior & 3 & 27448681 & 9149560 & 16,88256 & 0,001382 & & & \\
\hline Residual & 7 & 3793674 & 541953,4 & & & & & \\
\hline \multirow[t]{2}{*}{ Total } & 10 & 31242355 & & & & & & \\
\hline & Coefficients & andard Err & t Stat & $P$-value & Lower 95\% & Upper 95\%. & ower 95,0\% & Ipper 95,0\%, \\
\hline Intercept & 5313,83 & 1126,079 & 4,71888 & 0,00216 & 2651,077 & 7976,583 & 2651,077 & 7976,583 \\
\hline $\operatorname{div}$ & 39,09156 & 7,090226 & 5,513443 & 0,000894 & 22,32584 & 55,85728 & 22,32584 & 55,85728 \\
\hline ret ear & $-41,0615$ & 5,832501 & $-7,04011$ & 0,000204 & $-54,8531$ & $-27,2698$ & $-54,8531$ & $-27,2698$ \\
\hline dummy & $-5727,54$ & 943,4173 & $-6,07106$ & 0,000505 & $-7958,37$ & $-3496,71$ & $-7958,37$ & $-3496,71$ \\
\hline
\end{tabular}

Even the financial crises affected the share's price negatively as presented by the dummy's variable coefficient. Because the dependent variable is expressed in absolute values and the time specific dummy variables are dichotomous by nature, in order to capture the presence (or the absence) of certain circumstances at some point of time (such as the years of the financial crisis), the coefficient estimates of the included dummies would not be concerned as a true (unbiased) representatives of the effects of those circumstances on the movements of the dependent variable. To express the effects accurately, we can use the approximate dummy variable estimation approach [30], but only for the variables expressed in log values. According to it, if $b$ is the estimated coefficient on a dummy variable and $V(b)$ is the estimated variance of $b$, then $g$ gives an estimate of the percentage impact of the dummy:

$$
g=100\left(\exp \left(b-\frac{1}{2} V(b)\right)-1\right)
$$

If we apply the formula and convert the dummy coefficient from the log regression, the result will be $51 \%$. This means that the presence of a circumstance of crises, reduces the price of Alkaloid's share by $51 \%$ during the observed period. The final conclusion from the performed microanalysis, is that at least in the case of $A D$ Alkaloid - Skopje, a valid evidence is found for confirmation of the hypothesis that stockholders will choose dividend payments to avoid the uncertainty due to price appreciation. 


\section{Discussion}

There are many controversies concerning the dividend policy as a determinant of the firm's valuation. One of the most recognizable academic duo - Modigliani \& Miller are amongst the leading critics as they explain in their Dividend Irrelevance Hypothesis, but others such as Myron Gordon strongly support the idea that implementation of a proper dividend policy can in fact shape the company's value. The academic work of these pioneers in the field of dividend policy and valuation, inspired many others to follow their steps in the quest for answers, triggering a cascade of literature in the second half of the 20-th century. In this article we give a small contribution to the effort and try to answer the question whether the implemented dividend policy is an important valuation factor for the resident company. For that purpose, we used the Gordon's idea about "the Bird in the Hand Hypothesis" to see how it works for the leading domestic companies. First, the originally constructed model intended for panel-data research was applied on the aggregate data from the 10 most advanced companies that constitute the $\mathrm{MBI}-10$ index. But the regression from the macro-data analysis didn't justify our expectations as the results were statistically insignificant and inconclusive. To correct for the anomalies, in our second attempt we used more consistent and synchronized data for the aggregate dividends and retentions, but couldn't separate the individual price weight of the excluded companies from the aggregate index $\mathrm{MBI}$. Once again the results from the regression were invalid and we couldn't find any confirmation of the relevance of dividend policy on a macro (aggregate) level. Searching for the answers for why it failed, we conclude from our analysis the following possible reasons:

- Fundamental assumption fallacy: the model ignores the impact of the externally funded investments on the growth, assuming that it depends exclusively from reinvestments of retentions;

- Inappropriate use of aggregate data: the model might not be suitable for application in terms of aggregate data;

- Incomplete or incorrect data: lack of information from 3 companies for the amounts of dividends and retained earnings distributed;

- Inconsistent data: the exclusion of data for the 3 companies out of the independent variables was not compensated adequately for the dependent variable;

- Inappropriate medium for evaluation: the dependent variable MBI-10, which is the reference aggregate price index for the Macedonian stock exchange market, may be influenced by the way earnings are distributed, but also by many other factors of determination.

- Existence of possible hidden variable: the model with the aggregate data could be extended with a couple of independent variables that define the movements of $\mathrm{MBI}$ 10 more concisely;

- Specific industry risk difference: the model doesn't account for the difference in the risk level among the different industries, and among companies with different stage of the life cycle (young or mature);

- Unstandardized measurements of dividends and retained earnings: companies might use different methods and accounting procedures for the purpose. It's worth to mention that many of the observed companies come from the banking sector, known for its specific approach in the loss reserves policy.

- Insufficient data: although with normal distribution, sometimes the small number of observations could bias the outcome of a regression.

The next step in the research was to evaluate the Gordon's model on a set of data from an individual company, in our case AD Alkaloid - Skopje. In this micro-analysis, the basic regression was slightly modified with extension of a fixed (dummy) variable to separate the years of economic crisis aimed to stabilize the variations of share's price. This time the regression performed more successfully with results that were both significant and conclusive. The application of "Bird in the Hand" model revealed that that for every million denars in dividend payment the share price increases by 39 denars, and for every million 
denars retained the price decreases by 41 denars. Even the financial crises, reduced the price of Alkaloid's share by $51 \%$ during the observed period, as the converted coefficients of dummy showed. This means that in the case of $A D$ Alkaloid - Skopje, the thesis for the relevance of dividend policy has found its background and confirmation at least on a micro level.

\section{References}

1 Lease, Ronald C., Kose John, Avner Kalay, Uri Loewenstein, and Oded H. Sarig, Dividend Policy: Its Impact on Firm Value (Harvard Business School Press, Boston, Massachusttes), 2000;

2 Moyer Mc Guigan Kretlow, Contemporary Financial Management, Eight editions, Southwestern College Publishing, 2001.

3 Frankfurter, George M., and Bob G. Wood, The Evolution of Corporate Dividend Policy, Journal of Financial Education 23, 1997; 16-33.

4 Al-Malkawi H.A., Rafferty M., Pillai R., "Dividend Policy: A Review of Theories and Empirical Evidence", International Bulletin of Business Administration, EuroJournals, Inc. 2010.

5 Al-Malkawi H.A., Rafferty M., Pillai R., "Dividend Policy: A Review of Theories and Empirical Evidence", International Bulletin of Business Administration, EuroJournals, Inc. 2010.

6 Black, Fischer, 1976, The Dividend Puzzle, Journal of Portfolio Management 2, 5-8.

7 Miller M.H., Modigliani F., "Dividend Policy, Growth, and the Valuation of Shares", Journal of Business, 1961;

8 Fama E.F., French K.R., "Disappearing Dividends: Changing Firm Characteristics or Lower Propensity to Pay?", Journal of Financial Economics, 2001;

9 Allen, F., Antonio E.B., Ivo W.,, 2000, "A Theory of Dividends Based on Tax Clienteles", Journal of Finance, 2000;

10 Gordon M. J., "Dividends, Earnings, and Stock Prices", Review of Economics and Statistics, 1959;

11 Gordon M. J., "Dividends, Earnings, and Stock Prices", Review of Economics and Statistics, 1959;

12 Al-Malkawi H.A., Rafferty M., Pillai R., "Dividend Policy: A Review of Theories and Empirical Evidence", International Bulletin of Business Administration, EuroJournals, Inc. 2010.

13 P.R. Richardson., "Taxes, Transactions costs and the Clientele Effect of Dividends", Journal of Financial Economics;

14 Lipson M.L., Maquieira C.P., William M., "Dividend Initiations and Earnings Surprises", Financial Management, 1998;

15 Soter D., Eugene B., Paul E., "The Dividend Cut Heard' Round The World: The Case of FPL", Journal of Applied Corporate Finance, 1996.

16 Rozeff M.S., "Growth, Beta and Agency Costs as Determinants of Dividend payout Ratios", The Journal of Financial Research, 1982;

17 EasterbrookF. H., "Two Agency Costs Explanations of Dividends", American Economic Review, 1984;

18 Gordon M. J., "Dividends, Earnings, and Stock Prices", Review of Economics and Statistics, 1959;

19 Gordon, Myron J., Optimal Investment and Financing Policy, Journal of Finance 18, 1963;

20 Fisher G.R., "Some Factors Influencing Share Prices", Economic Journal, 1961;

21 Diamond, James J., Earnings Distribution and the Valuation of Shares: Some Recent Evidence, Journal of Financial and Quantitative Analysis 2, 1967;

22 Lintner, John., Dividends, Earnings, Leverage, Stock Prices and Supply of Capital to Corporations, The Review of Economics and Statistics 64, 1962;

23 Walter, James E., Dividend Policy: Its Influence on the Value of the Enterprise, Journal of Finance 18, 1963; 
24 Miller M.H., Modigliani F., "Dividend Policy, Growth, and the Valuation of Shares", Journal of Business, 1961;

25 Rozeff, Michael S., Growth, Beta and Agency Costs as Determinants of Dividend payout Ratios, The Journal of Financial Research 5, 1982;

26 Diamond, James J., Earnings Distribution and the Valuation of Shares: Some Recent Evidence, Journal of Financial and Quantitative Analysis 2, 1967;

27 Diamond, James J., Earnings Distribution and the Valuation of Shares: Some Recent Evidence, Journal of Financial and Quantitative Analysis 2, 1967;

28 Al-Malkawi H.A., Rafferty M., Pillai R., "Dividend Policy: A Review of Theories and Empirical Evidence", International Bulletin of Business Administration, EuroJournals, Inc. 2010.

29 Baker, H. Kent, E. Theodore Veit, and Gary E. Powell, 2001, Factors Influencing Dividend Policy Decisions of Nasdaq Firms, The Financial Review 38, 19-3;

30 Kennedy, P., "Estimation with Correctly Interpreted Dummy Variables in Semilogarithmic Equations", American Economic Review, 1981; 